\title{
WS3
}

\section{Basin Modelling and Sequence Stratigraphy Analysis for Exploration. Model Building Workshop}

\author{
S.M. Astakhov* (Schlumberger)
}

\section{SUMMARY}

The workshop attendees will have an opportunity to real-time examining the main processes of petroleum systems modelling on the example of Russian sedimentary basin study in latest Petromod software. Application of the sequence stratigraphy analysis using additional software is a tool for reservoir prognosis and paleowater depth restoration for subsequent basin modelling and reservoirs charging in traps estimation. 
During presentation of new geophysical features, recently developed by Schlumberger, workshop attendees will get possibility to observe evolution of geophysical interpretation process and learn about ongoing further innovations in this area of geosciences. We want to show the evolution of seismic interpretation from the simple and familiar to everyone geophysics methods to modern algorithms that are implemented in the software package Petrel, demonstrate the potential of a multi-interpretation of 2D - 3D seismic data, and ways to manage these data, tools, quality control and interpretation of the wording, automatic detection of structural features. But the main thing we want to say that this topic is not yet worked out to the end, Schlumberger continues to develop the existing algorithms and create new ones, to make the process easier and simplify interpretation, and most importantly to save your time on building proper structural models. We will demonstrate a new approach to constructing a structural model, which runs concurrently with the correlation, it is our latest addition.

\section{Выход сейсмической интерпретации на новый уровень развития}

Цель доклада - показать эволюцию сейсмической интерпретиции от самых простых и привычных каждому геофизику методов до современных алгоритмов, которые реализованы в программном комплексе Petrel; продемонстрировать возможности многооконной интерпретации 2D-3D сейсмических данных и способов управления этими данными, инструментов контроля качества и редакции интерпретации, автоматического выделения структурных особенностей. Но главное, мы хотим сказать, что эта тема ещё не исчерпана полностью, компания Шлюмберже продолжает развивать существующие алгоритмы и создавать новые, чтобы сделать процесс интерпретации лёгким и простым, а главное - сэкономить время геофизиков на построение корректной структурной модели. Мы продемонстрируем новый подход построения структурной модели, который выполняется одновременно с процессом корреляции, это наша последняя разработка для построения самых сложных структур. 